\title{
Description of Integrated Science Process Skills in Physics Education Students in Convex Mirror Practicum
}

\author{
Sinta Oktavia \& Utari Prisma Dewi (*) \\ Universitas Jambi
}

\author{
Received: October 20, 2020 \\ Revised: May 29, 2020 \\ Accepted: June 24, 2020
}

\begin{abstract}
This study aims to determine the description of students towards the use of ICT-based convex mirror material guidebooks. The population of this study was the students of Jambi University Physics Education class program in 2018. The sampling technique used was total sampling, so that the sample of this study was all physical education students at University of Jambi with 105 students in class 2018. Indicators of observed process skills included the process of identifying variables, making data tables, making a graph, explaining the relationship between variables, obtaining and processing data, analyzing investigations, making hypotheses, identifying variables by vocational, designing experiments and conducting experiments. Process skill data was measured through a basic physics practicum performance evaluation sheet when practitioners conducted convex mirror practicum activities. Data was analyzed using descriptive statistics. The analysis shows that the average Science Process Skills are categorized as good and very good. This points out that the students have mastered the integrated Science Process Skills. The results of this study are expected to be a consideration for physics study programs to conduct related studies for other practicum subjects.
\end{abstract}

Keywords: Science Process Skills, Convex Mirror, physical education

(*) Corresponding Author: utariprismadewi@gmail.com

How to Cite: Oktavia, S. \& Dewi, U.P. (2020). Description of integrated science process skills in physic education students in convex mirror practicum. Formatif: Jurnal Ilmiah Pendidikan MIPA, 10 (2): 103114. http://dx.doi.org/10.30998/formatif.v10i2.5036

\section{INTRODUCTION}

Physic Education Study Program at Universitas Jambi has graduate competencies that also refer to the Indonesian National Qualification Framework (KKNI) including attitudes, knowledge and skills. The main focus of learning in higher education is to actively involve students in the learning process (Astalini, Kurniawan \& Sumaryanti, 2018). Skills that must be mastered by physics education students are science process skills. Science process skills are the ability to process actions as well as scientific thought in order to develop an understanding of scientific concepts to support subsequent abilities. According to Darmaji (2018), process skills are important for students to solve physics problems in the surrounding environment and during the learning process.

Science process skills are divided into two parts of basic process skills and integrated process skills (Darmaji, Kurniawan \& Irdianti, 2019). These Science Process Skills are very important to be mastered by physics students. It is based on all forms of learning activities both in the classroom and in the laboratory begun with an observation (Astalini, 2019; Kurniawan, \& Astalini, 2019). Students as prospective physics teachers or professional educators have the task of guiding, training and building student's 
knowledge. According to (Astalini, 2019), students must master the science process skills, because most of the physics taught is emphasizing the material that is centered on activity. An important task of a science educator is to help students develop the thinking skills of scientists (Darmaji, Kurniawan \& Rahayu, 2018).

A physics teacher or prospective physics teacher who does not have science process skills, when teaching in class can only convey concepts with conventional teaching methods (Maison, 2019). This makes students treat physics as a collection of knowledge and tend to only master the concepts of physics without understanding the process of occurrence (Darmaji, Kurniawan \& Lestari, 2018; Maison, 2018). Physics learning requires students to be active in the learning process, students not only master concepts but are also trained in mindset and shape students' personalities in life (Kurniawan \& Parasdila, 2018). Jambi University Physics Education Study Program has 4 graduate competencies, one of which is skills competency. The study program as a place to produce professional teacher candidates must ensure the achievement of these competencies (Astalini, 2019).

Darmaji (2018) said that science process skills consist of basic process skills (observing, summarizing, measuring, communicating, classifying, predicting, using timespace relations and using numbers are part of basic process skills) and integrated process skills (identifying variables, building data tables, building graphs, describing relationships between variables, obtaining and processing data, analyzing investigations, constructing hypotheses, defining variations operationally, designing investigations, and experimenting). The process skills that are focused in this study are integrated process skills consisting of identifying variables, making data tables, making graphs, describing relationships between variables, obtaining and processing data, analyzing investigations, making hypotheses, identifying variables by operational, designing experiments and carrying out an experiment. Basic and integrated science process skills are very important to be mastered by physics education students as prospective teachers (Kurniawan, 2018; Lestari, 2017). The application of process skills in learning is something that must be implemented by teachers in their learning (Hardiyanti, 2018). Process skill is a teachinglearning approach that leads to the growth and the development of a number of specific skills in prospective teacher students, so that they are able to process information to discover new things that are useful in the form of facts, concepts, attitude and value development (Kurniawan, 2019; Astalini, 2018).

Science process skill is a teaching-learning approach that leads to the growth and development of a number of specific skills in students, in order to be able to process information so that new things that are useful in the form of facts, concepts and the development of attitudes and values. Science process skills serve to encourage students to develop the knowledge they have received (Kurniawan, Astalini \& Sari, 2019). Practicum activities can be used as activities to improve or to develop students' scientific skills including psychomotor aspects (Kurniawan \& Parasdila, 2018). According to Aydin (2013), science process skills are thinking abilities that we use to create knowledge, to reflect on problems and to formulate results. Science process skills involve skills that require more complex experiences (Kurniawan, Perdana \& Kurniasari, 2018).

To be successful in practicum activities, besides using good tools, it must also be supported by a practicum implementation guide or practicum guide. The practicum guide is one of the teaching materials used as student's guidelines in carrying out practicum (Maison, Darmaji, Astalini, Kurniawan \& Indrawati, 2019). According to Kurniawan, Lumbantoruan \& Samosir (2019), in many school science programs, these laboratories are used in a cookbook fashion to verify scientific facts but not to promote laboratory or science process skills to study the natural phenomenon. Thammasaeng (2018), achieving 
ICT literacy skills is useful in researching, setting up systems and evaluating information in which can promote effective learning and working. This statement is in accordance with that contained in the practicum guide in physics education.

ICT has been widely used in learning such as assessment and guidebooks. Handbooks conducted using ICT will greatly assist in the assessment of science process skills in the reflection experiments on convex mirrors. As we know now that there is a glimmer of hope that teachers can help and assess their students to be better with the help of ICT (Cener, et. al, 2015). Reflection is a physics concept that is studied in physics practicum. Reflection is a nature of light where it can be learned through practical activities (Myers, 2013). The existence of ICT will shorten the time of the assessment because the assessment is no longer done manually. The development of ICT in the field of education is characterized by the use of computers to create practical, interesting and interactive learning (Kurniawan, Anwar \& Kurniawan, 2019). Therefore the remaining time can be as much as possible dedicated in the process of reflection on a convex mirror. Thus, the use of ICT-based guidebooks help students do practicum according to the purpose of convex mirror material which is aimed to determine the nature of the image from the object based on the distance of the object to the convex mirror, to determine the focus distance of the convex mirror, and to identify the effect of changing the distance of the object to the distance of the shadow and the distance of the point of focus/fire/focus on a convex mirror.

\section{METHOD}

This present research used a quantitative approach with experimental research method. The type of research used is the true experimental type in the form of post-test control and experimental group design. True experiments comprise the most rigorous and strong experimental designs because of equating the groups through random assignments (Creswell, 2012). This study aims to determine the description of students towards the use of ICT-based guidebooks with printed guidebooks on convex mirror material on the science process skills of students so that in this study using the post-test control end experimental group design.

This study consisted of two groups, namely the experimental group and the control group. The experimental group was the group that was treated and used ICT-based guidebooks on convex mirror material. While the control group was the group that was not treated and used a printed manual on convex mirror material.

The population in this study was physics education study program students who contracted in the elementary physics courses II, totaling 105 students. The sample used in this study was the random sampling method. Random sampling is also known as sampling probability. Random sampling is where each member of the population has the same probability of being a research sample. This technique is considered as the best technique for getting a representative sample (Kothari, 2004; Gratton \& Jones, 2004). The sample used was 64 students, with 34 students being treated, while 30 students were not treated.

The instrument used in this study was an instrument of students' science process skills using a Likert scale as scoring of each statement. The selection of the four scales used was to determine the research criteria, namely: (1) Very Not Good; (2) Not Good; (3) Good; (4) Very Good. The instrument used in this study consisted of 16 indicators, of which the integrated science process skills consisting of 7 indicators. 
The data of students' science process skills obtained will be tested for normality and homogeneity then will be analyzed using a different test with a statistical t-test that was aimed to determine the mastery of students' science process skills which were grouped into 4 criteria seen in table 1.

\begin{tabular}{ccc}
\multicolumn{3}{c}{ Table 1. Mastery of Interval Scores for Students' } \\
\hline No & Interval & Category \\
\hline 1 & $1,00-1,75$ & Very Not Good \\
2 & $>1,75-2,50$ & Not Good \\
3 & $>2,50-3,25$ & Good \\
4 & $>3,25-4,00$ & Very Good \\
\hline
\end{tabular}

\section{RESULTS AND DISCUSSION}

\section{Results}

Based on the analysis conducted, practicum guides based on mobile learning on average make students' integrated Science Process Skills increase. The followings are the results of a descriptive analysis of students' integrated Science Process Skills in the Convex Mirror experiment.

Table 2. Student Science Process Skills on Variable Identification Indicators

\begin{tabular}{|c|c|c|c|c|c|c|c|c|}
\hline \multicolumn{5}{|c|}{ Classification } & \multirow[t]{2}{*}{ Mean } & \multirow[t]{2}{*}{ Median } & \multirow[t]{2}{*}{ Min } & \multirow[t]{2}{*}{ Max } \\
\hline $\begin{array}{r}\text { Indicator } \\
\text { (Class) }\end{array}$ & $\begin{array}{c}\text { Interval } \\
\text { score }\end{array}$ & Category & Total & $\%$ & & & & \\
\hline \multirow{4}{*}{$\begin{array}{l}\text { Variable } \\
\text { Identification } \\
\text { (Experiment) }\end{array}$} & $2.0-3.5$ & Very Not Good & 0 & 0 & 6.64 & 6.50 & 5.00 & 8.00 \\
\hline & $3.6-5.1$ & Not Good & 5 & 14.7 & & & & \\
\hline & $5.2-6.7$ & Good & 12 & 35.3 & & & & \\
\hline & $6.8-8.0$ & Very Good & 17 & 50.0 & & & & \\
\hline Total & & & 34 & 100 & & & & \\
\hline \multirow{4}{*}{$\begin{array}{c}\text { Variable } \\
\text { Identification } \\
\text { (Control) }\end{array}$} & $2.0-3.5$ & Very Not Good & 0 & 0 & 6.27 & 6.00 & 5.00 & 8.00 \\
\hline & $3.6-5.1$ & Not Good & 7 & 23.3 & & & & \\
\hline & $5.2-6.7$ & Good & 15 & 50.0 & & & & \\
\hline & $6.8-8.0$ & Very Good & 8 & 26.7 & & & & \\
\hline Total & & & 30 & 100 & & & & \\
\hline
\end{tabular}

Table 2 shows that the science process skills on the indicator of variable identification, both the experiment class and the control class are categorized as very good and good. In the experiment class, the highest percentage in the excellent category is $50.0 \%$, whereas the control class has the highest percentage in the good category of $50.0 \%$. Based on these data, it can be seen that the students' science process skills on the variable identification indicator, both the experiment class and the control class have been well mastered when carrying out convex mirror practicums. This is based on the ability of students when identifying variables on 3 things that need to be observed, namely the ability of students to declare independent variables, dependent variables and constant variables in a convex mirror practicum. In the experiment class, students are able to determine the variables that exist in the convex mirror practicum. While in the control class, students hesitate to determine the variables that exist in convex mirror practicum activities. Students tend to trust their friends' arguments more than themselves. 
Table 3. Student Science Process Skills on Indicators of Creating Data Tables

\begin{tabular}{|c|c|c|c|c|c|c|c|c|}
\hline \multicolumn{5}{|c|}{ Classification } & \multirow[t]{2}{*}{ Mean } & \multirow[t]{2}{*}{ Median } & \multirow[t]{2}{*}{ Min } & \multirow[t]{2}{*}{ Max } \\
\hline $\begin{array}{c}\text { Indicator } \\
\text { (Class) }\end{array}$ & $\begin{array}{c}\text { Interval } \\
\text { score }\end{array}$ & Category & Total & $\%$ & & & & \\
\hline \multirow{4}{*}{$\begin{array}{c}\text { Creating Data } \\
\text { Tables } \\
\text { (Experiment) }\end{array}$} & $4.0-7.0$ & Very Not Good & 0 & 0 & 13.20 & 13.00 & 13.00 & 4.00 \\
\hline & $7.1-10.0$ & Not Good & 4 & 11.4 & & & & \\
\hline & $10.0-13.0$ & Good & 17 & 48.6 & & & & \\
\hline & $13.1-16.0$ & Very Good & 13 & 40.0 & & & & \\
\hline Total & & & 34 & 100 & & & & \\
\hline \multirow{4}{*}{$\begin{array}{c}\text { Creating Data } \\
\text { Tables } \\
\text { (Control) }\end{array}$} & $4.0-7.0$ & Very Not Good & 0 & 0 & 12.87 & 13.00 & 14.00 & 2.00 \\
\hline & $7.1-10.00$ & Not Good & 3 & 10.0 & & & & \\
\hline & $10.1-13.0$ & Good & 14 & 46.7 & & & & \\
\hline & $13.1-16.0$ & Very Good & 13 & 43.3 & & & & \\
\hline Total & & & 30 & 100 & & & & \\
\hline
\end{tabular}

Table 3 shows that the science process skills on the indicator of creating data tables, both the experiment class and the control class are in the good category. In the experimental class, the highest percentage in the good category is $48.6 \%$ and the control class also has the highest percentage in the good category of $46.7 \%$. This is based on the results of the experimental data that have been obtained by both the experiment class and the control class, students only write experimental data from the first to the last experiment without making a special data table for each experiment conducted.

Table 4. Student Science Process Skills Indicators of Making Graphs

\begin{tabular}{|c|c|c|c|c|c|c|c|c|}
\hline \multicolumn{5}{|c|}{ Classification } & \multirow[t]{2}{*}{ Mean } & \multirow[t]{2}{*}{ Median } & \multirow[t]{2}{*}{ Min } & \multirow[t]{2}{*}{ Max } \\
\hline $\begin{array}{l}\text { Indicator } \\
\text { (Class) }\end{array}$ & $\begin{array}{c}\text { Interval } \\
\text { score }\end{array}$ & Category & Total & $\%$ & & & & \\
\hline \multirow{4}{*}{$\begin{array}{l}\text { Making Graphs } \\
\text { (Experiment) }\end{array}$} & $2.0-3.5$ & Very Not Good & 1 & 2.9 & 11.52 & 11.00 & 6.00 & 24.00 \\
\hline & $3.6-5.1$ & Not Good & 14 & 41.2 & & & & \\
\hline & $5.2-6.7$ & Good & 19 & 55.9 & & & & \\
\hline & $6.8-8.0$ & Very Good & 14 & 40.0 & & & & \\
\hline \multirow[t]{2}{*}{ Total } & & & 34 & 100 & & & & \\
\hline & $2.0-3.5$ & Very Not Good & 9 & 30.0 & 9.23 & 9.00 & 6.00 & 12.00 \\
\hline \multirow{3}{*}{$\begin{array}{l}\text { Making Graphs } \\
\quad \text { (Control) }\end{array}$} & $3.6-5.1$ & Not Good & 10 & 33.3 & & & & \\
\hline & $5.2-6.7$ & Good & 11 & 36.7 & & & & \\
\hline & $6.8-8.0$ & Very Good & 0 & 0 & & & & \\
\hline Total & & & 30 & 100 & & & & \\
\hline
\end{tabular}

Table 4 shows that the science process skills on the indicators of making graphs, both the experiment class and the control class are in a good category. In the experiment class, the highest percentage in the good category is $55.9 \%$ and in the control class also has the highest percentage in the good category of $36.7 \%$. Based on these data, it can be seen that the experiment class students have a greater percentage of making graphs than the control class. This skill is closely related to the skill of creating data tables, the better the skill to create data tables, the better the skill to make graphs. Students in the experiment class who are able to make tables in the experiment are interested in making some graphs related to the data that has been obtained during the practicum. While in the control class, students only make a relation graph in accordance with the examples in the lab guide. 
Table 5. Student Science Process Skills on Indicators of Describing Relationships between Variables

\begin{tabular}{|c|c|c|c|c|c|c|c|c|}
\hline \multicolumn{5}{|c|}{ Classification } & Mean & Median & Min & Max \\
\hline $\begin{array}{l}\text { Indicator } \\
\text { (Class) }\end{array}$ & $\begin{array}{l}\text { Interval } \\
\text { score }\end{array}$ & Category & Total & $\%$ & & & & \\
\hline Describing & $3.00-5.25$ & Very Not Good & 0 & 0 & 9.43 & 9.00 & 7.00 & 12.00 \\
\hline Relationships & $5.26-7.50$ & Not Good & 5 & 14.3 & & & & \\
\hline between & $7.51-9.75$ & Good & 16 & 48.6 & & & & \\
\hline $\begin{array}{c}\text { Variables } \\
\text { (Experiment) }\end{array}$ & $9.76-12.00$ & Very Good & 13 & 37.1 & & & & \\
\hline Total & & & 34 & 100 & & & & \\
\hline Describing & $3.00-5.25$ & Very Not Good & 0 & 0 & 8.80 & 9.00 & 6.00 & 12.00 \\
\hline Relationships & $5.26-7.50$ & Not Good & 8 & 26.7 & & & & \\
\hline between & $7.51-9.75$ & Good & 13 & 43.3 & & & & \\
\hline $\begin{array}{l}\text { Variables } \\
\text { (Control) }\end{array}$ & $9.76-12.00$ & Very Good & 9 & 30.0 & & & & \\
\hline Total & & & 30 & 100 & & & & \\
\hline
\end{tabular}

Table 5 shows that the science process skills on the indicators of describing the relationships between variables, both the experiment class and the control class are categorized in the good category. In the experiment class, the highest percentage in the good category is $48.6 \%$ and in the control class, the highest percentage in the good category is $43.3 \%$. In indicators of describing the relationship between variables, the ability of students to make a matching line (graph) and the relationship between numbers of repeated measurements with the measurement results are obtained. In the experiment class and the control class, students are interested in adding the repetition of the experiment to obtain valid data in accordance to the advice explained in the practical guide.

Table 6. Student Science Process Skills on the Indicators of Obtaining and Processing Data

\begin{tabular}{|c|c|c|c|c|c|c|c|c|}
\hline \multicolumn{5}{|c|}{ Classification } & \multirow[t]{2}{*}{ Mean } & \multirow[t]{2}{*}{ Median } & \multirow{2}{*}{\multicolumn{2}{|c|}{ Min $\operatorname{Max}$}} \\
\hline $\begin{array}{c}\text { Indicator } \\
\text { (Class) }\end{array}$ & Interval Score & Category & Total & $\%$ & & & & \\
\hline Obtaining and & $9.00-15.75$ & Very Not Good & 0 & 0 & 28.77 & 28.00 & 21.0 & 34.00 \\
\hline Processing & $15.76-22.51$ & Not Good & 3 & 8.6 & & & & \\
\hline Data & $22.52-29.27$ & Good & 17 & 48.6 & & & & \\
\hline (Experiment) & $29.28-36.00$ & Very Good & 14 & 42.9 & & & & \\
\hline Total & & & 34 & 100 & & & & \\
\hline Obtaining and & $9.00-15.75$ & Very Not Good & 0 & 0 & 28.07 & 29.00 & 21.0 & 35.00 \\
\hline Processing & $15.76-22.51$ & Not Good & 5 & 16.7 & & & & \\
\hline Data & $22.52-29.27$ & Good & 14 & 46.7 & & & & \\
\hline (Control) & $29.28-36.00$ & Very Good & 11 & 36.7 & & & & \\
\hline Total & & & 30 & 100 & & & & \\
\hline
\end{tabular}

Table 6 shows that the science process skills on the indicator of obtaining and processing data, both the experiment class and the control class are categorized as good. In the experiment class, the highest percentage in the good category is $48.6 \%$ and in the control class, the highest percentage in the good category is $46.7 \%$. The indicator of obtaining and processing data is dealing with the students' ability to display the experimental data in the form of data tables and graphs. In the experiment class and the control class, students are interested in adding the repetition of the experiment to obtain 
valid data in accordance to the advice explained in the practical guide. The data is moved into the form of data tables and graphs.

Table 7. Student Science Process Skills in Analyzing Investigations Indicators

\begin{tabular}{|c|c|c|c|c|c|c|c|c|}
\hline \multicolumn{5}{|c|}{ Classification } & \multirow[t]{2}{*}{ Mean } & \multirow[t]{2}{*}{ Median } & \multirow[t]{2}{*}{ Min } & \multirow[t]{2}{*}{ Max } \\
\hline $\begin{array}{l}\text { Indicator } \\
\text { (Class) }\end{array}$ & $\begin{array}{c}\text { Interval } \\
\text { Score }\end{array}$ & Category & Total & $\%$ & & & & \\
\hline \multirow{4}{*}{$\begin{array}{c}\text { Analyzing } \\
\text { Investigations } \\
\text { (Experiment) }\end{array}$} & $2.0-3.5$ & Very Not Good & 0 & 0 & 6.64 & 6.50 & 5.00 & 8.00 \\
\hline & $3.6-5.1$ & Not Good & 5 & 14.7 & & & & \\
\hline & $5.2-6.7$ & Good & 12 & 35.3 & & & & \\
\hline & $6.8-8.0$ & Very Good & 17 & 50.0 & & & & \\
\hline Total & & & 34 & 100 & & & & \\
\hline \multirow{4}{*}{$\begin{array}{c}\text { Analyzing } \\
\text { Investigations } \\
\text { (Control) }\end{array}$} & $2.0-3.5$ & Very Not Good & 0 & 0 & 6.27 & 6.00 & 5.00 & 8.00 \\
\hline & $3.6-5.1$ & Not Good & 7 & 23.3 & & & & \\
\hline & $5.2-6.7$ & Good & 15 & 50.0 & & & & \\
\hline & $6.8-8.0$ & Very Good & 8 & 26.7 & & & & \\
\hline Total & & & 30 & 100 & & & & \\
\hline
\end{tabular}

Table 7 shows that the science process skills on the indicators of analyzing investigations, both the experiment class and the control class are categorized as very good and good. In the experiment class, the highest percentage in the excellent category is $50.0 \%$. Whereas the control class has the highest percentage in the good category of $50.0 \%$. The indicator of analyzing investigations reviews the students' ability to adjust and to decide that the experiment they conducted is in accordance to his hypothesis. In this case, students should have confidence in their ideas on the design and on the experimental plans they have thought of. Students in the experiment class are able to carry out experimental activities properly because the experimental procedures are explained coherently on the practicum guide. Whereas students in the control class tend to need laboratory assistant demonstrations to help them understand the experimental procedure. Therefore, around 15 students with a percentage of 50\% in the control class are in a good category.

Table 8. Student Science Process Skills on Operational Variable Identification Indicators

\begin{tabular}{|c|c|c|c|c|c|c|c|c|}
\hline \multicolumn{5}{|c|}{ Classification } & Mean & Median & Min & Max \\
\hline $\begin{array}{l}\text { Indicator } \\
\text { (Class) }\end{array}$ & $\begin{array}{c}\text { Interval } \\
\text { Score }\end{array}$ & Category & Total & $\%$ & & & & \\
\hline Operational & $2.0-3.5$ & Very Not Good & 0 & 0 & 6.46 & 6.00 & 5.00 & 8.00 \\
\hline Variable & $3.6-5.1$ & Not Good & 5 & 14.3 & & & & \\
\hline Identification & $5.2-6.7$ & Good & 13 & 40.0 & & & & \\
\hline (experimental) & $6.8-8.0$ & Very Good & 16 & 45.7 & & & & \\
\hline Total & & & 34 & 100 & & & & \\
\hline Operational & $2.0-3.5$ & Very Not Good & 1 & 3.3 & 6.00 & 6.00 & 3.00 & 8.00 \\
\hline Variable & $3.6-5.1$ & Not Good & 8 & 26.7 & & & & \\
\hline Identification & $5.2-6.7$ & Good & 11 & 36.7 & & & & \\
\hline (Control) & $6.8-8.0$ & Very Good & 10 & 33.3 & & & & \\
\hline Total & & & 30 & 100 & & & & \\
\hline
\end{tabular}

Table 8 shows that the science process skills in the indicators of operational variable identification, both the experiment class and the control class are very good and good. In the experiment class, the highest percentage in the excellent category is $45.7 \%$. Whereas the control class has the highest percentage in the good category of $36.7 \%$. The indicator of operational variable identification reviews the students' ability to determine the results of 
experiments conducted using tools that are appropriate to the experiments conducted. Students in the experiment class are able to determine the results of the experiment well according to the tools and experimental procedures described in the lab guide. Whereas students in the control class tend to need the assistance of laboratory assistants to determine the results of the experiment and to understand the procedure of the experiment.

Based on the results seen in table above, it is known that the Science Process Skills of students have been well mastered when carrying out convex mirror practicum. This shows that the average mastery of Science Process Skills is integrated both in the experiment group and the control group on the indicators studied has been categorized as good and very good. In the experiment class, making graphics is an indicator with the highest percentage of $55.9 \%$ in the good category. Whereas in the control class, the identification of variables and analyzing investigations are the highest indicators with a percentage of $50.0 \%$ that are categorized as good.

\section{Discussion}

Science process skills are abilities needed by students to support the practicum activities they do in the laboratory. These abilities consist of two types of science process skills, namely basic science process skills and integrated science process skills. Turiman, et. al., (2012) say that science process skills consist of basic process skills (observing, summarizing, measuring, communicating, classifying, predicting, using time-space relationships and using numbers are parts of basic process skills) and integrated process skills (identifying variables, creating data tables, making graphs, describing relationships between variables, obtaining and processing data, analyzing investigations, building hypotheses, defining variations operationally, designing investigations and experiment). In this study, 7 indicators of integrated process skills are reviewed (identifying variables, creating data tables, making graphs, describing relationships between variables, obtaining and processing data, analyzing investigations, identifying variables by operational). In the indicator of variables identification, there are 3 things need to be observed through students' ability to declare variables appropriately, namely: independent variables, dependent variables and constant variables.

Based on table 2, it can be seen that the students' science process skills on the variable identification indicator, both the experiment class and the control class have been well mastered when carrying out the convex mirror practicum. The next indicator is to create a data table, based on table 3 , it can be seen that students are more likely to do practical activities compared to writing the experimental results in tabular form. Based on table 4, which is making graphics closely related to the skills to create data tables, the better the skill of creating data tables, the better the skill to make graphs. Students in the experiment class who are able to create experimental data tables are interested in making several graphs related to the variables they identify. Whereas students in the control class only make a relationship graph in accordance with the examples in the practicum guide. Some students are not interested in communicating their findings through graphs. This shows that students do not have a good attitude. Positive student attitudes toward physics will have a sense of fun when the learning process takes place (Astalini, et. al, 2018). In addition, the limitations of the findings presented through the data tables are one of the factors that make students feel lazy to communicate their findings through the data tables. In the indicators of describing the relationship between variables, the ability of students to make a matching line (graph) the relationship between the number of repeated measurements with the measurement results have been obtained. In the experiment class 
and the control class, students are interested in adding the repetition of the experiment to obtain valid data in accordance to the advice explained in the practical guide.

Based on table 5, the indicator describes the relationship between variables, in terms of the ability of students to make a matching line (graph), the relationship between the numbers of repeated measurements with the measurement results have been obtained. In the experimental class and the control class, students are interested in adding the repetition of the experiment to obtain valid data in accordance to the advice explained in the practical guide. In the indicators of obtaining and processing data in table 6 , it deals with the ability of students to display experimental data in the form of data tables and graphs. In the experiment class, students are interested in adding the repetition of the experiment to obtain valid data in accordance to the advice explained in the practical guide. Students should have previous experience of observing, classifying and measuring before interpreting data (Ozgelen, 2012). The ability of students to show their findings is closely related to the basic science process skills possessed by students. Whereas the investigative analysis indicators in table 7 review the students' ability to adjust and to decide that the experiments conducted are in accordance to their hypotheses. In this case, students should have confidence in their ideas on the design and the experimental plans they have thought of. And in table 7, the indicator of identification variables operationally, reviews the students' ability to determine the results of experiments conducted using tools that are appropriate to the experiments conducted. Students in the experiment class are able to determine the results of the experiment appropriately according to the tools and to the experimental procedures described in the lab guide. Meanwhile, students in the control class tend to need the assistance of laboratory assistants to determine the results of the experiment and to understand the procedure of the experiment.

The importance of science process skills for physics education students, where science process skills themselves are skills that facilitate learning in physics, ensure students active participation, develop students' sense of responsibility in their own learning, improve permanent learning, and also make students gain ways and methods of research, which is ensuring thinking and behaving like a scientist. From the several indicators reviewed in the observations made, the results of the science process skills of the indicator students varied from the categories of very not good, not good, good and very good. The integrated process skills in convex mirror practicum activities found that the average science process skills of the experiment class and control class students are of good and very good categories. This is based on the ability of students who are classified as high in practical activities. However, each class has a dominant aspect of science process skills. In the experiment class, making graphs is an indicator with the highest percentage of $55.9 \%$ categorized as good. Whereas in the control class, identifying variables and analyzing investigations are the highest indicators with a percentage of $50.0 \%$ that are categorized as good category.

Each class has its own way of practicing. The attitude in learning is very important, as is the attitude in learning towards college subjects (Astalini, et. al., 2018). Students in the experiment class are also able to use e-modules directly in the laboratory without being demonstrated. This shows that students are ready to use technology in learning. Online based mobile learning provides opportunities for students to study anytime and anywhere (Astalini, et. al., 2019). The mastery of integrated science process skills in students who are classified as good shows that Physics Education students have a good stock as prospective educators, especially in the field of Physics. 


\section{CONCLUSION}

The integrated science process skills of the experiment class students who are in the good category are the skills of creating data tables, making graphs, describing relationships between variables, as well as obtaining and processing data. The integrated science process skills of the experiment class students who are in the excellent category are operational skills for identifying variables, analyzing investigations and identifying variables. While the integrated science process skills of control class students are in a good category. Integrated process skills in convex mirror practicum activities are found that the average science process skills of students are in good and very good categories. This is based on the ability of students who are classified as high on this practicum. The results of this study are as initial descriptions of science process skills with advantages in order to improve students' science process skills through practical activities using ICTbased guidebooks. While the weakness in this study is the difficulty of students in adapting to use practicum guides that require students to do practicums independently. Physics education study programs should be able to apply ICT-based practical manuals to improve science process skills through practical activities.

\section{REFERENCES}

Astalini, A., Kurniawan, D. A., \& Sumaryanti, S. (2018). Sikap siswa terhadap pelajaran fisika di SMAN Kabupaten Batanghari. JIPF (Jurnal Ilmu Pendidikan Fisika), 3(2), 59-64.

Astalini, A., Kurniawan, D. A., Kurniawan, N., \& Anggraini, L. (2019). Evaluation of Student's Attitude toward Science in Indonesia. Open Journal for Educational Research, 3(1), 1-12.

Astalini, A., Kurniawan, D. A., Melsayanti, R., \& Destianti, A. (2019). Sikap terhadap mata pelajaran IPA di SMP se-Kabupaten Muaro Jambi. Lentera Pendidikan: Jurnal Ilmu Tarbiyah dan Keguruan, 21 (2), 214-227.

Astalini, A., Kurniawan, D. A., Perdana, R., \& Pathoni, H. (2019). Identifikasi sikap peserta didik terhadap mata pelajaran fisika di sekolah menengah atas negeri 5 Kota Jambi. UPEJ Unnes Physics Education Journal, 8 (1), 34-43.

Astalini, A., Kurniawan, D. A., Sari, D. K., \& Kurniawan, W. (2019). Description of scientific normality, attitudes of investigation and interested career on physics in senior high school. JIPF (Jurnal Ilmu Pendidikan Fisika).

Astalini, A., Maison, M., Ikhlas, M., \& Kurniawan, D. A. (2018). The development of students' attitude instrument towards mathematics physics class. EDUSAINS, 10(1), 46-52.

Aydin, A. (2013). Representation of science process skills in the chemistry curricula for grades 10, 11 And 12/Turkey. International Journal of Education and Practice, 1 (5), 51-63.

Çener, E., Acun, İ., \& Demirhan, G. (2015). The impact of ICT on pupils' achievement and attitudes in social studies. Journal of Social Studies Education Research, 6 (1), 190-207. https://doi.org/10.17499/jsser.67856

Creswell, J.W.(2012). Educational Research: Planning, Conducting and Evaluating Quantitaty and Qualitatif Research. Lincoln: University of Nebraska.

Darmaji, D., Kurniawan, D. A., \& Irdianti, I. (2019). Physics Education Students' Science Process Skills. International Journal of Evaluation and Research in Education, 8 (2), 293-298. 
Darmaji, D., Kurniawan, D. A., \& Lestari, A.. (2018). Deskripsi keterampilan proses sains mahasiswa pendidikan fisika pada praktikum suhu dan kalor. JRKPF UAD, 5 (2).

Darmaji, D., Kurniawan, D. A., \& Rahayu, A. (2018). Development physics practical guided based on science process skill using problem solving. Edusains, 10 (1), 8396.

Darmaji, D., Kurniawan, D. A., \& Suryani, A. (2019). Effectiveness of basic physics II practicum guidelines based on science process skills. JIPF (Jurnal Ilmu Pendidikan Fisika), 4 (1), 1-7.

Darmaji, D., Kurniawan, D. A., H Parasdila, I Irdianti\& Lestari, A. (2018). Deskripsi keterampilan proses sains mahasiswa pendidikan fisika pada praktikum suhu dan kalor. Berkala Ilmiah Pendidikan Fisika, 6 (3), 345-353.

Darmaji, D., Kurniawan, D. A., Suryani, A., \& Lestari, A. (2018). An identification of physics pre-service teachers' science process skills through science process skillsbased practicum guidebook. Jurnal Ilmiah Pendidikan Fisika Al-Biruni, 7 (2), 239245.

Gratton. C \& Jones. I. 2004. Research Methods for Sport Studies. London: Routledge.

Hardiyanti, K., Astalini, A., \& Kurniawan, D. A. (2018). Sikap siswa terhadap mata pelajaran fisika di Sma Negeri 5 Muaro Jambi. EduFisika: Jurnal Pendidikan Fisika, 3 (02), 1-12.

Kothari. C.R. (2004). Research Methodology: Methods \& Techniques. New Delhi: New Age International (P) Limited.

Kurniawan, D. A., \& Astalini, A. (2019). Evaluasi sikap siswa SMP terhadap IPA di Kabupaten Muaro Jambi. Jurnal Ilmiah Didaktika: Media Ilmiah Pendidikan dan Pengajaran, 19 (1), 124-139.

Kurniawan, D. A., \& Parasdila, H. (2018). Description of science process skills' physics education students at jambi university in temperature and heat materials. The Educational Review, USA, 2 (9), 485-498.

Kurniawan, D. A., Astalini, A., \& Sari, D. K. (2019). An evaluation analysis of students' attitude towards physics learning at senior high school. Jurnal Penelitian dan Evaluasi Pendidikan, 23 (1), 26-35.

Kurniawan, D. A., Astalini, A., Kurniawan, N., \& Pathoni, H. (2019). Analisis korelasi sikap siswa dan disiplin siswa terhadap IPA pada Siswa SMP Provinsi Jambi. Jurnal Pendidikan Fisika dan Keilmuan (JPFK), 5(2), 59.

Kurniawan, D. A., Lumbantoruan, A., \& Samosir, S. C. (2019). Mobile learning in higher education for the industrial revolution 4.0: Perception and response of physics practicum. International Journal of Interactive Mobile Technologies, 13 (9).

Kurniawan, D. A., Perdana, R., \& Kurniasari, D. (2018). Identification of student attitudes toward physics learning at Batanghari district high school. The Educational Review, USA, 2 (9), 475-484.

Kurniawan, D., A., Darmaji., Astalini., Peni Sefiah I. (2018). Description of science process skills for physicsteacher's candidate. Azerbaijan Journal of Educational Studies, 684 (3), 71-85.

Kurniawan, W., Anwar, K., \& Kurniawan, D. A. (2019). Effectiveness of using e-module and e-assessment. International Journal of Interactive Mobile Technologies, 13 (9).

Lestari, U. (2017). Deskripsi keterampilan proses sains mahasiswa pendidikan fisika universitas jambi pada kegiatan praktikum fisika dasar 1 (Keterampilan proses sains: Observasi, prediksi, klasifikasi dan kesimpulan). Edu Fisika.

Maison, Darmaji, Astalini, Kurniawan, D. A., \& Indrawati, P. S. (2019). Science process skills and motivation. Humanities \& Social Sciences Reviews, 7 (5), 48-56. 
Maison, M., Astalini, A., Kurniawan, D. A., \& Yuniyarsih, S. (2018). Student's attitude description toward physics on secondary school. Edusains, 10 (1), 160-167.

Myers, R. L. (2013). The Basics of Physics. London: Greenwood Press. https://doi.org/10.5860/choice.43-6587

Ozgelen, S. (2012). Students' science process skills within a cognitive domain framework. Eurasia Journal of Mathematics, Science \& Technology Education, 8 (4), 283-292.

Thammasaeng, P.,Pupat, P., \& Petchaboon, S. (2018). Needs assessment of information and communication technology literacy (ICT Literacy) of students in secondary educational service area. iJET, 11 (12), https://doi.org/10.3991/ijet.v11i12.5798

Turiman, P., Omar, J., Daud, A. M., \& Osman, K. (2012). Fostering the 21st century skills through scientific literacy and science process skills. Procedia-Social and Behavioral Sciences, 59, 110-116. 